\title{
Development and Operation of the Dalian Cruise Port in China
}

\author{
Lina Gong (D) \\ School of Economics and Management, Shanghai Maritime University, Shanghai, China \\ Correspondence should be addressed to Lina Gong; gonglina2002@163.com
}

Received 15 November 2021; Accepted 22 January 2022; Published 16 February 2022

Academic Editor: Tingsong Wang

Copyright (c) 2022 Lina Gong. This is an open access article distributed under the Creative Commons Attribution License, which permits unrestricted use, distribution, and reproduction in any medium, provided the original work is properly cited.

China's cruise industry has developed rapidly in the past ten years, and China's cruise port construction has flourished. A total of 20 cities along the coast of mainland China have built or planned to build cruise terminals. According to WTO estimates, China will gradually become the world's largest source country of cruise passengers and cruise travel consumers in the future. Due to different national conditions, the business model and development prospects of Chinese cruise ports are different from those of foreign ports. It requires finding the pioneers of domestic cruise ports to take the lead, providing advice on the development and operation of cruise ports. Dalian Cruise Port is actively formulating its cruise industry development plan, expanding the cruise port, and improving the supporting facilities in the cruise port area. Based on the characteristics of the operation of the Dalian cruise port, we use the gray model to make a vague prediction of the future development of the cruise port. It reflects the advanced operation mode of Dalian Port. This research systematically analyzed cruise port operations and maritime cruise transportation. Because the cruise port's business model and prospects are essential to the cruise port industry, China's cruise ports must learn more advanced operating models.

\section{Introduction}

The new corona-virus disease pandemic in early 2020 has also disrupted various industries, such as the health sector, tourism, supply chain, marketing companies, entertainment industry, food, and beverage industry, capital and currency markets, international trade, and shipping industries [1]. Among them, Cruise ship movements can be a major trigger of corona-virus disease (COVID-19) outbreaks [2]. Governments' travel restrictions on tourists and people's worries about the risks posed by travel have greatly affected the shipping industry [3]. COVID-19 has severely affected the cruise ship tourism industry, trapping thousands of workers and customers on cruise ships and posing health and wellbeing risks [4].

The cruise industry is one of the fastest growing and most dynamic parts of the entire tourism and leisure travel market [5]. More and more customers are interested in cruise travel because they are considered new, different, and very interesting. A cruise vacation is an elite leisure method, with multiple advantages such as accommodation, transportation, catering, entertainment, tourism, and shopping [6].

The global cruise industry has experienced extraordinary growth in terms of financial performance and passenger numbers [7]. Since 1980, global cruise passengers' average annual growth rate has been $8.4 \%$ [8], more than 32 million passengers on nearly 300 ships [9]. The cruise home port industry will significantly impact the regional economy, and its economic benefits will be 10 to 14 times those of a standard port. On the one hand, the cruise industry significantly impacts regional economic development. The cruise industry and cruise service area will attract many products, capital, technology, and talents and generate economies of scale; on the other hand, the cruise industry is a very comprehensive service industry. It takes cruise ships like the carrier, brings leisure, sightseeing, and entertainment as specific content and is related to shipbuilding and ship maintenance. Industries such as transportation, tourism, catering, shopping, and ship supplies are closely related, which determines that the cruise industry's multiplier benefit is more significant. 
In order to better develop China's cruise port industry chain, it is necessary to compare and analyze the operation and development of domestic cruise ports. This topic is based on the analysis and prediction of the Dalian International Cruise Port to suggest the operation and development of China's cruise port.

\section{Status Quo of Dalian Port Cruise Industry}

2.1. Domestic Cruise Terminal. On June 26, 2010, the home port of Tianjin International Cruise Line officially opened and ushered in the first international luxury cruise liner, Costa's "Romantic," which started its maiden voyage in China back then. Cruise is described as 'any fare-paying voyage for leisure on-board a vessel whose primary purpose is the accommodation of guests and not normally freight to visit a variety of destinations rather than to operate on a set route [10]." In 2012, to meet the development needs of large cruise ships, Tianjin Port International Cruise Home Port began to go through the construction procedures of the second phase of the terminal. It passed the acceptance of the hydraulic part of the project on December 31, 2013. At present, the port has four cruise berths, which can berth 450,000 -ton cruise ships or three large-scale cruise ships of 50,000 to 150,000 tons at the same time. The shoreline of the terminal is 1,112 meters.

Tianjin International Cruise Home port is the second "China Cruise Tourism Development Experimental Zone" in China. It is located in the Tianjin Dongjiang Free Trade Port Zone, with excellent port infrastructure and a total customs clearance capacity of 920,000 passengers per year. In 2018, a total of 116 inbound and outbound cruise ships were received, and the throughput of inbound and outbound passengers reached 683,000 . In 2019, a total of 116 international cruises were received, which was the same as in 2018, with 693,000 inbound and outbound cruise passengers.

It implemented the 144-hour transit visa-free policy for foreigners in some countries, opened cruise port entry dutyfree shops, and guided consumption return, piloted the cruise ship ticket system, enabled self-service inspection channels at ports, and improved user experience. Royal Caribbean Cruises, Costa Cruises, and Mediterranean Cruises use Tianjin as their home port and open routes here. Tianjin International Cruise Line is located in the core area of the Bohai Rim and Northeast Asia cruise routes. Although it has achieved remarkable results, compared with other international cruise home ports such as Shanghai, its port is far from urban areas. There are cruise ships such as Dalian and Qingdao in the hinterland port; the cold weather in winter is unsuitable for cruise tourism; the port and tourism hardware supporting facilities, personnel services, and other software supporting facilities still need to be further improved.

2.2. The Relationship between the Development of the Cruise Market in Dalian Port and the Economic Development Level of the Three Northeastern Provinces. During the ten years from
2009 to 2020, the GDP per capita of the three northeastern provinces showed an overall growth trend (Figure 1). If calculated according to the current World Bank purchasing power parity data (1 USD 6.9 RMB, the same below), the per capita GDP of Liaoning, Jilin, and Heilongjiang in 2018 was USD 8,299, USD 7,956, and USD 6,191, respectively. At present, the per capita GDP of the three northeastern provinces has exceeded US $\$ 5,000$. However, none of them has reached US $\$ 10,000$, indicating that the foundation for the development of the cruise tourism industry in these regions is already in place. However, it is still in the incubation stage and has not yet reached the outbreak period.

\section{Development Goals of Dalian Port Cruise Port}

3.1. Overall Goal. Since the 21st century, the cruise shipping industry has diverted their development to all budgets, markets, and geographical regions [11]. Seize the opportunity of Dalian's free trade zone and "China Cruise Tourism Development Experimental Zone" to form an internationalized, legalized, standardized, accessible, convenient, and internationally competitive cruise home port operating policy environment and introduce a normalized and serialized policy environment and incentive measures to build a domestic and international first-class cruise home port infrastructure system, route pattern, multilevel product system, collection and distribution system, ship supply system, consumer shopping system, and leisure travel system to attract domestic and foreign passengers, cruise routes, and cruise ships. The capabilities of core and supporting industries such as enterprises, ship supply companies, transaction display, bonded logistics, cruise maintenance, financial insurance, cross-border e-commerce, and other cruise home port core and supporting industry elements have rapidly increased, driving Dalian's tourism, high-end consumption, cruise shipbuilding, leisure and entertainment, and talents, as well as the development of cruise related industries such as training.

3.2. Stage Goals. Short term: 2020-2025. After the next five years of development, a cruise operating environment that is in line with international standards will be formed, the critical cruise industry has been extensively developed, the cruise industry system has been continuously improved, and a cruise operation center, ship supply center, and cruise ship with substantial influence in Northeast Asia will be built as a tourism base. Complete the construction of the cruise home port and supporting facilities. The number of international cruises is $80-100$ voyages per year, the number of passengers sent annually reaches 200,000, and the number of cruise ships with Dalian Port as the home port reaches 5-7. A combination of high seas cruises, global cruise routes, offshore cruise routes, domestic coastal tourism routes, and inland river cruises on the Yangtze River has basically taken shape. Relying on policies and measures such as passenger clearance, shore sightseeing, tax-free shopping, visa-free entry, visa-free transit, 


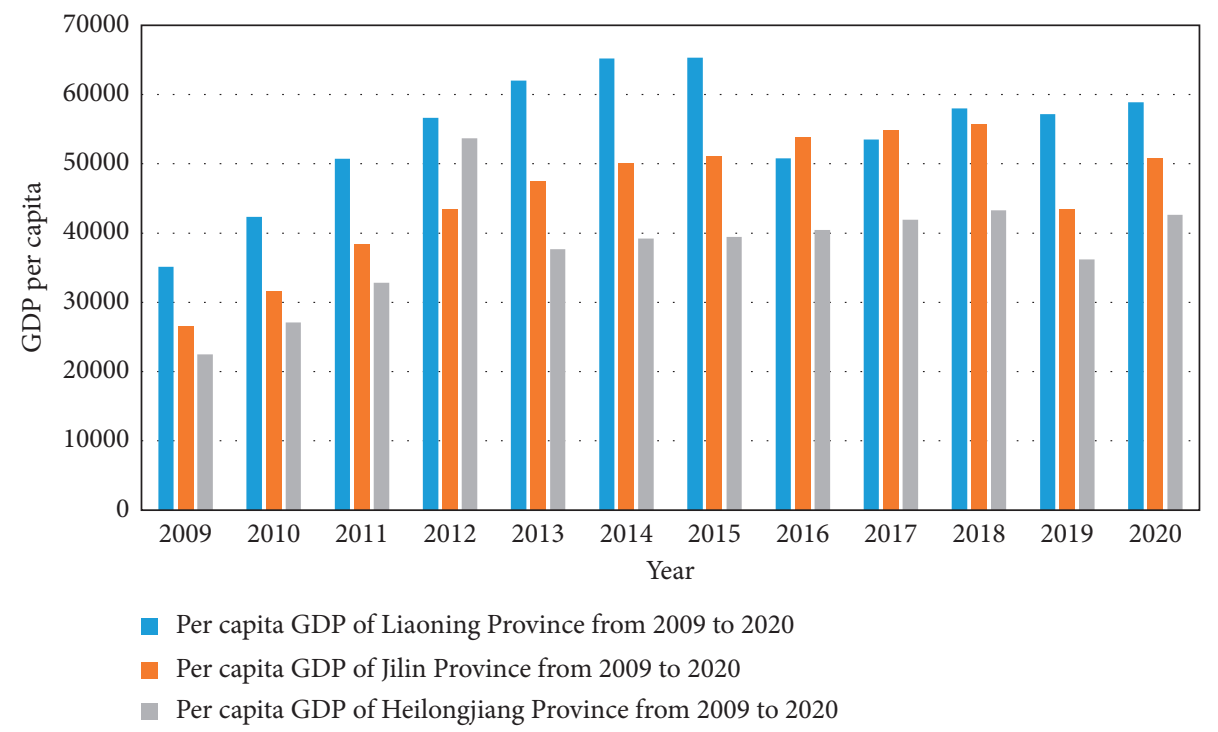

Figure 1: Per capita GDP of the three provinces in Northeast China from 2009 to 2020(yuan/person). Source: National Bureau of Statistics.

multipoint calling on routes, global procurement of ship supplies, facilitation of inspection and quarantine, and bonded maintenance in the free trade zone, continuous innovation has formed an international competition-powerful institutional system. The main body of cruise tourism marketing continues to be enriched, and the marketing business and methods are innovated. The cruise portfolio products suitable for different types of tourists are rich and diverse, initially forming a cruise tourism center with particular influence in Northeast Asia. The cruise city of "ships, ports, cities, travel, shopping, and entertainment" has initially taken shape, and the economic stimulus of cruise ships has been significantly improved.

Long term: 2025-2030. By 2030, the number of cruise ships using Dalian Port as the home port will reach more than 10 , and the annual passenger volume of cruise port will reach more than 360,000 , and its ability to attract domestic and foreign tourists is leading in China. Develop a variety of tourism products with Dalian characteristics and make full use of before and after disembarkation to attract tourists to stay in Dalian. Value-added core industries such as cruise ship supply, cruise ship maintenance, and cruise city thrive form a complete multilevel and multigradient cruise economic development ecology. Supporting industries such as cruise-related financial transactions, creative cruise design, cruise cultural display, cruise conferences, and exhibitions have gradually improved, becoming one of the famous cruise core cities in Northeast Asia.

3.3. Overall Path. To realize the vision, positioning, and goals of the cruise industry in Dalian Port, strategic planning needs to be implemented from the perspectives of home port construction and development model, facility planning, functional design, market development, route layout, product development, multisubject coordination, and policy innovation.
3.4. Dalian Cruise Port Development. As a port of call, Dalian is the first city in China to receive international cruise ships (Figure 2). The boom of the modern cruise industry began in the late 1960s and early 1970s [12]. In 1976, Dalian Port was the first to receive a cruise ship, "Coral Princess," from Japan. Since then, Dalian Port has received international cruise ships from Europe, America, Japan, and South Korea. At most, the Dalian Cruise Port has as many as 68 cruise ships arriving at the port in about a year. Since the reform and opening up, the number of cruise ships received by Dalian International Cruise Port has always been among the best in the country. In this process, Dalian Cruise Port has accumulated rich experience in reception services for large cruise ships. From 2005 to 2013, the cruise ships "Sapphire Princess" and "Diamond Princess" under US Princess Cruises visited Dalian Port for many years. In July 2016, the Dalian Port International Cruise Center officially opened. The cruise ship berth 10-11 \# on the west side of the second terminal in Dagang District achieved a 70,000-ton cruise ship berthing capacity. Royal Caribbean's 70,000-ton "Ocean Myth" completed departing from Dalian Port. In 2018, Dalian Port upgraded the No. 10-11 berth in Dagang District to a 150,000-ton cruise berth, making it suitable for receiving 150,000-ton luxury cruise ships. At the same time, Dalian Port is also stepping up efforts to upgrade the 8-9\# berth on the east side of the second wharf of Dagang District into a 150,000-ton cruise berth (the hydraulic structure will reserve to 225,000-ton level) to upgrade the berth level further. With the subsequent construction of the Dalian International Cruise Center, the number of international cruise voyages and the number of inbound and outbound passengers at the Dalian International Cruise Port will increase qualitatively.

In recent years, the Dalian cruise market has developed rapidly. The cruise industry is developing rapidly, and academic research is increasing day by day [13]. According to data from the Dalian Port cruise business, in 2017, it received 69,000 inbound and outbound passengers, a year-on-year 

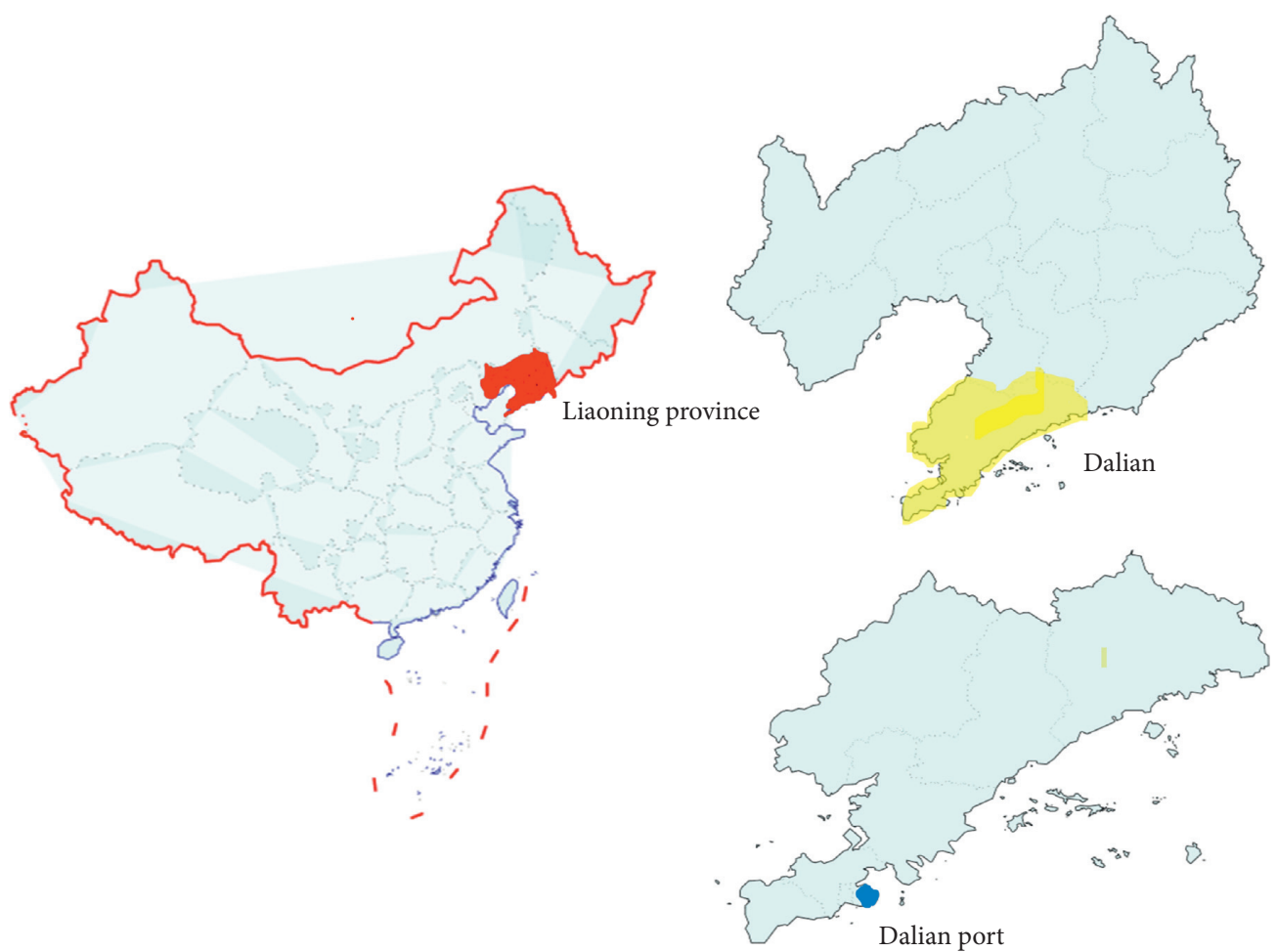

Figure 2: Research region (Port of Dalian).

growth rate of $6.6 \%$. In 2018 , it reached 85,000 , achieving a growth of more than $20 \%$. This has promoted the establishment and operation of Dalian's local cruise company to a certain extent. In 2019, a total of 88,500 inbound and outbound cruise tourists had received a year-on-year increase of 4.7\%. In February 2014, Shandong Bohai Ferry Co., Ltd. invested and established Bohai Cruise Co., Ltd., headquartered in Hong Kong. Its 24,500-ton "China Taishan" is China's first wholly owned, independently operated, and managed international luxury cruise ship. In August 2015, "Zhonghua Taishan” used Dalian as the home port to operate the originating route to South Korea, which enabled Dalian to make specific progress in cruise operation and management and initially broke the monopoly of the three major cruise groups. With the increase in the number of cruise ships received, Dalian has also accumulated relatively rich experience in cruise reception over the past 30 years. It has adopted flexible inspection methods to inspect cruise tourists, which can save tourists sightseeing time and bring tremendous value to service personnel on cruise ships. Great convenience: Dalian has accumulated specific experience in the reception services and the maintenance and overhaul of cruise ships after they arrive in Hong Kong. The development of the cruise reception business has accelerated the pace of planning and construction of the Dalian cruise port. In recent years, the infrastructure construction related to Dalian cruise tourism has gradually improved. The waterway of Dalian Bay Dagang has a water depth of $-11 \mathrm{~m}$ and good wind shelter conditions, capable of docking 150,000 tons of luxury Cruise ships. The waterway design of Dalian East Port is very reasonable. The water quality in the port area is excellent, is pollution-free, and has no silt deposits, suitable for the berthing of cruise ships. Ample space provides a solid foundation for the development of cruise tourism in Dalian, which is suitable for the development of the cruise economy.

3.5. Prediction of GDP per Capita in the Three Northeastern Provinces. Forecasting GDP per capita in Liaoning Province from 2009 to 2020 (Table 1), whether the per capita GDP growth rate in Liaoning Province has been fast or slow, the overall trend is increasing. From the perspective of the growing trend of per capita GDP, the average annual growth rate of per capita GDP in Liaoning Province in the past ten years was 5.4\%, and the growth rate from 2014 to 2018 was slower than that of the previous five years.

From 2009 to 2020, the per capita GDP of Jilin Province maintained continuous growth (Table 1). From the perspective of the growing trend of per capita GDP, the average annual growth rate of per capita GDP in Jilin Province in the past ten years was $8.5 \%$, but the growth rate from 2014 to 2018 has declined significantly.

Forecasting Heilongjiang Province's GDP per capita In 2013, the per capita GDP of Heilongjiang Province fell by nearly $30 \%$. However, the per capita GDP has begun to rebound in the past five years, and the overall growth has been maintained. The average growth rate from 2009 to 2018 was $7.5 \%$ (Table 1 ).

It is estimated that the average annual growth rate of per capita GDP in Liaoning Province will be 5\% and 3\% in 2019-2025 and 2026-2030, respectively. Based on this, the predicted per capita GDP of Liaoning Province in 2020, 2025, and 2030 can be calculated and converted into US 
TABle 1: Per capita GDP of three northeastern provinces from 2009 to 2020.

\begin{tabular}{|c|c|c|c|c|c|}
\hline \multicolumn{6}{|c|}{ Per capita GDP of Liaoning province from 2009 to 2020} \\
\hline Year & Per capita GDP(yuan/person) & Growth rate $(\%)$ & Year & Per capita GDP(yuan/person) & Growth rate $(\%)$ \\
\hline 2009 & 35149 & - & 2015 & 65354 & 0.23 \\
\hline 2010 & 42355 & 20.50 & 2016 & 50791 & -22.28 \\
\hline 2011 & 50760 & 19.84 & 2017 & 53527 & 5.39 \\
\hline 2012 & 56649 & 11.60 & 2018 & 58008 & 8.37 \\
\hline 2013 & 61996 & 9.44 & 2019 & 57191 & -1.4 \\
\hline 2014 & 65201 & 5.17 & 2020 & 58872 & 2.93 \\
\hline \multicolumn{6}{|c|}{ Per capita GDP of Jilin province from 2009 to 2020} \\
\hline Year & Per capita GDP(yuan/person) & Growth rate $(\%)$ & Year & Per capita GDP(yuan/person) & Growth rate $(\%)$ \\
\hline 2009 & 26595 & - & 2015 & 51086 & 1.8 \\
\hline 2010 & 31599 & 18.8 & 2016 & 53868 & 5.4 \\
\hline 2011 & 38460 & 21.7 & 2017 & 54838 & 1.8 \\
\hline 2012 & 43415 & 12.9 & 2018 & 55611 & 1.4 \\
\hline 2013 & 47428 & 9.2 & 2019 & 43475 & -21.9 \\
\hline 2014 & 50160 & 5.8 & 2020 & 50799 & 16.8 \\
\hline \multicolumn{6}{|c|}{ Per capita GDP of Heilongjiang province from 2009 to 2020} \\
\hline Year & Per capita GDP(yuan/person) & Growth rate $(\%)$ & Year & Per capita GDP(yuan/person) & Growth rate $(\%)$ \\
\hline 2009 & 22477 & - & 2015 & 39462 & 0.6 \\
\hline 2010 & 27076 & 20.6 & 2016 & 40432 & 2.5 \\
\hline 2011 & 32819 & 21.2 & 2017 & 41916 & 3.7 \\
\hline 2012 & 53711 & 63.7 & 2018 & 43274 & 3.2 \\
\hline 2013 & 37697 & -29.8 & 2019 & 36183 & -16.4 \\
\hline 2014 & 39226 & 4.1 & 2020 & 42635 & 17.8 \\
\hline
\end{tabular}

Source: National Bureau of Statistics.

dollars (Table 2); they are approximately US\$9732, US\$11,266, and US\$13,060, respectively.

It is estimated that the average annual growth rate of per capita GDP in Jilin Province from 2019 to 2025 and from 2026 to 2030 is $2 \%$ and $1.5 \%$, respectively. Based on this, the per capita GDP forecast value of Jilin Province in 2020, 2025, and 2030 can be calculated and converted into US dollars (Table 2); they are about 8385 US dollars, 9258 US dollars, and 9973 US dollars.

It is estimated that the average annual growth rate of per capita GDP in Heilongjiang Province from 2019 to 2025 and from 2026 to 2030 is $3.5 \%$ and $4 \%$, respectively. Based on this, the predicted per capita GDP of Heilongjiang Province in 2020, 2025, and 2030 can be calculated and converted into US dollars; they are approximately US\$6,718, US\$7,979, and US $\$ 9,708$, respectively (Table 2 ).

In summary, the per capita GDP of Liaoning Province is expected to exceed US\$10,000 in recent years. In comparison, the per capita GDP of Jilin Province and Heilongjiang Province will also reach US\$10,000 in 2030. Therefore, the cruise industry of Dalian Port may reach an outbreak period before 2030.

\subsubsection{The Vision and Positioning of the Dalian Port Cruise} Port. Vision of first-class home port for cruise ships in Northeast Asia: compared with the internationally leading cruise home port, after ten years of construction and development, infrastructure, collection, and distribution, cruise routes, cruise products, cruise ship supply, port supervision, and financial taxation systems equivalent to the world's high-level cruise home ports have been formed. With the cruise home port as the core, the upstream, middle
TABLE 2: Forecast results of the three provinces.

Forecast results of per capita GDP in Liaoning province from 2020 to 2030

\begin{tabular}{lrrr} 
Year & 2020 & 2025 & 2030 \\
\hline $\begin{array}{l}\text { Per capita GDP of Liaoning province } \\
\text { (yuan) }\end{array}$ & 67151 & 77736 & 90117 \\
$\begin{array}{l}\text { GDP per capita in Liaoning province } \\
\text { (USD) }\end{array}$ & 9732 & 11266 & 13060
\end{tabular}
(USD)

Forecast results of per capita GDP in Jilin province from 2020 to 2030

\begin{tabular}{llll} 
Year & 2020 & 2025 & 2030 \\
\hline Per capita GDP of
\end{tabular}

\begin{tabular}{lllll}
\hline Per capita GDP of Jilin province (yuan) & 57858 & 63880 & 68816
\end{tabular}

Per capita GDP of Jilin Province(USD) $\quad 8385 \quad 9258 \quad 9973$

Forecast results of Heilongiiang Province's per capita GDP from 2020 to 2030

Year

$2020 \quad 2025 \quad 2030$

Per capita GDP of Heilongiiang province

(yuan)

Per capita GDP of Heilongjiang province (USD)

$4635655056 \quad 66984$

$\begin{array}{lll}6718 & 7979 & 9708\end{array}$

and downstream industrial chain and value chain system including leisure, sightseeing, amusement, food distribution, ship supply, cruise maintenance, catering and shopping, finance, and insurance are gradually formed and improved. With the development of "travel, shopping, and entertainment," the cruise home port ecosystem is accelerating its formation. Cruise companies, travel agencies, financial insurance, material distribution, cruise maintenance, and tax-free shopping are gradually gathering to promote the economic development of cruise ships and become first class in Northeast Asia. The cruise operation center, cruise 
tourism base, and cruise ship supply center form a "development pole" that proliferates and generates a powerful radiating effect on the development of the city of Dalian.

3.5.2. Strategic Positioning. The first-class cruise operation center in Northeast Asia: compared with the high standards of international cruise home port construction, aiming to create a more attractive international cruise city, perfecting and optimizing the layout of functional facilities such as transportation, tourism, culture, shopping, and catering and accelerating the construction of a commercial complex with cruise characteristics, etc., service industry projects strengthen the route advantages of China, Japan, South Korea, and Southeast Asia, accelerate the formation of regular high sea cruises, offshore cruise routes, and domestic coastal tourism routes, and gradually explore the development of ocean and global cruise routes. Built based on cruise ship berthing, passenger and crew embarkation, cruise replenishment, passenger clearance, baggage check, travel services, crew services, and other functions, based on cruise ship supply, cruise route opening, joint development of multilevel cruise products, and global procurement of materials with distribution, high-end consumption, catering and shopping, tourism, and leisure as the core, the cruise home port developed with bonded display transactions, cruise maintenance, finance and insurance, conferences and exhibitions, cultural creativity, attracts cruise companies to use Dalian Port as a Northeast Asian operation and management base, attracting larger scale and multiple levels of passengers that have further increased the concentration of urban cruise-related industries. The experience of managing cruise ships is very important for creating customer function and health value [14].

The first-class cruise ship supply center in Northeast Asia: build a regional cruise ship supply center, set up a bright, large, comprehensive cruise ship supply logistics distribution center, form a collection of ultra-low temperature cold storage, professional logistics base, e-commerce platform, and carry out high-end food, spare parts, spare parts, and other distributions, and allocate and serve the home port of Dalian, radiate cruise companies, cruise ports, ship supply, logistics, and other companies in the surrounding ports of departure and visiting ports, and drive Dalian Port's duty-free shopping, bonded exhibitions, crossborder e-commerce, etc. to make breakthroughs and drive cruise supplies. The development of the cruise industry chain such as procurement, transportation, warehousing, distribution, and loading and unloading promotes the formation of a regional international cruise ship supply trading platform, attracts the participation of domestic and foreign enterprises, and gathers the elements of cruise ship supply.

The leading domestic cruise tourism base: the home port of Dalian Port International Cruise Line will be turned into a tourist attraction, linked with Dalian's local art galleries, museums, parks, beaches, and other attractions, and closely integrated with cruise tourism, attracting inbound and outbound passengers to stay, sightseeing, shopping, and spending at the home port, attracting domestic and foreign cruise tourists for play. Strengthen the cultural connotation and tourism landmark functions of cruise ships, promote the integration and interaction of the cruise industry, cultural resources, and tourism resources, promote the joint development of the cruise industry and other service industries, and provide unique characteristics for cruise passengers, surrounding residents, and citizens of Dalian and neighboring cities Cultural and leisure venues.

\section{Forecast Based on Hinterland Population Structure and Tourism Development Trend}

\subsection{Market Development}

\subsubsection{Differentiated and Customized Customer Source Market Development}

(1) Diversified Home Port Product Portfolio and Tourism Model. When formulating home port cruise tourism products, we must pay attention to the diversification of cruise products and services. In terms of tourist destinations, in addition to traditional international routes such as Japan and South Korea, other tourist destinations, especially the development of inland tourism products, should also be developed. The landscape scenery, characteristic architecture, folk customs, and urban amorous feelings of inland cities are also significant selling points to attract cruise tourists. Local tourists should be promoted to reach inland tourist destinations by cruise. At the same time, inland tourists will be brought to Dalian through cruise ships to promote the application of local characteristic tourism service resources and the development of outbound cruises with Dalian as the node. In terms of the tourism model and traditional cruise cruises, it should also combine the needs of tourists from different markets and regions. United Airlines, high-speed rail, and other transportation industries should develop innovations such as "aviation + cruise," "high-speed rail + cruise," and "inland cruise + outbound cruise." Tourism model: in terms of cruise entertainment, we will create a combination of sea and land tourism products, combining Dalian's local tourism resources and promoting tax-free shopping, hot spring health, and other comprehensive tourism products. In terms of cruise theme, the theme features of Dalian Cruise should be gradually built, and the development of special theme cruise projects can be tried from the aspects of wedding honeymoon, competitive events, celebration meetings, webcasts, etc., by the needs of the local and surrounding markets.

(2) Customization of Departure Port Products for Tourists:. Considering the different needs of tourists for cruise cruises, the arrangements for cruise tours at the departure port must be different and not the same. For young tourists, sightseeing cruises can be arranged to provide them with calm and free entertainment conditions; for nostalgic older adults, more attention should be paid to the comfort and safety of cruise ships, and performing arts and entertainment cruises can be arranged; for families visiting, most of the family tourists are to bring their children to broaden their horizons, enrich 
their experience, and pursue a comfortable environment, pay attention to children's interests and learning needs, and arrange bus cruises to coastal cities and scenic spots; for high-income groups, their pursuit is a more luxurious cruise travel, which can develop some luxurious routes or provide high-end artistic performances. Providing customized cruise projects for tourists with different consumption needs is the key to attracting tourists. Therefore, we should first accurately investigate the consumption needs of Dalian's local and surrounding cruise market. For cruise passengers with different needs, actively cooperate with governments, enterprises, schools, and locals. Tourism agencies cooperate in developing departure port cruise products suitable for tourists with different tourism needs.

\section{(3) Extensive Port Cooperation and Product Development for} Mutual Visiting Ports:. Strengthen cooperation with worldrenowned cruise home ports and cruise companies, and promote seasonal interaction between Dalian Port and internationally renowned cruise home ports. Focus on choosing an internationally renowned home port that complements Dalian's peak tourist season to form a seasonal cruise home port service mechanism to promote mutual call visits on major routes throughout the year. It will increase the international reputation of Dalian's cruise home port and promote the use of Dalian's local tourism resources. At the same time, it strengthens the in-depth cooperation with domestic ports, especially the joint tourism product development with surrounding cruise home ports. The Dalian cruise home port should rely on the existing cruise industry foundation and consider establishing a tourism mechanism that links the ports in the Bohai Rim region to facilitate cruise passengers with Dalian home port as the center to reach the Bohai Rim tourist destinations quickly. There are many home ports for cruise ships in the Bohai Rim, and the competition is fierce. It is necessary to cooperate with Tianjin, Qingdao, actively, and Yantai, cruise home ports, to jointly develop related cruise tourism products, strengthen cooperation, and create a cruise home port image with Chinese characteristics, so that the image of Chinese cruise tourism can penetrate the hearts of domestic consumers, thereby attracting more potential domestic consumers.

4.1.2. The Cruise Market Development Strategy under the Normalization of the Epidemic. As the global epidemic gradually gets under control, the global cruise industry has ushered in a restart signal. The cruise operation industry is in urgent need of recovery. The cruise shipbuilding industry has a dual-track operation of prevention, control, and production. The cruise industry will gradually transition from an "ice-bound area" to a "tacky area," and "the Asian cruise market has become a 'first mover." China has become one of Asia's most competitive tourist destinations and an important international tourist source market, especially for countries in the Asia-Pacific region [15]. Asia has stepped up to provide new facilities for the cruise industry to accommodate more and larger ships, especially Singapore,
Shanghai, Beijing (Tianjin), and Hong Kong [16]. China's cruise industry took the lead in regaining safety under the guidance of national policies, and the resumption of China's inland river cruises began in an orderly manner. Recently, the Ministry of Transport formulated the "Guidelines for the Normalization of Domestic Cruise Ships to Prevent and Control the Epidemic" to guide inland cruise ships to resume their navigation in a prudent and orderly manner. The Yangtze River cruise ship resumed navigation in August.

(1) Route Replanning and Layout. Under the normalization of the epidemic, various fields of the cruise economy will be fragmented. The current access of cruise ships will be strictly restricted. The richness and marketization of cruise routes depend on the national epidemic prevention and control policies and prevention and control levels of the routes. There will be a phenomenon that cruise operators in each region are operating independently. Under the global epidemic situation, due to problems such as inspection and quarantine, and entry, it is difficult for the cruise tourism industry to resume work and production across borders. However, it can innovate its product development and realize the domestic circulation of cruise tourism. After the cruise's restart, the routes include shortdistance routes provided near the home port, the development of domestic Sanya routes, South China Sea routes, southeast coastal routes, inland river routes, inland river + domestic main port routes, high sea routes, and destinationless upstream sea routes. Combining the urban tourism resources in the hinterland of the port, deepen the development of cruise + land tourism.

(2) Consumer-Oriented Marketing. On the one hand, the new crown pneumonia epidemic has affected tourists' confidence in choosing cruises and continuously negatively impacts people's willingness to travel. The "Survey Report on Chinese People's Traveling Willingness after the Epidemic," jointly released by China Tourism Research Institute and Ctrip Travel Big Data on March 20, 2020, shows that more than $90 \%$ of the respondents choose domestic travel. The three main choices are city-surrounding tours, domestic short- and medium-distance tours, and domestic longdistance tours, but there are more significant concerns about cruise travel. It is necessary to rebuild consumer confidence in cruise travel and continue to improve products and services. On the other hand, Chinese people still have a solid willingness to travel according to the tourism statistics of May 1 and National Day in 2020. Domestic consumers still tend to choose cruise travel under the premise of ensuring stable control of the epidemic and protection of cruise epidemic prevention. The consumer market has shown strong resilience. Combining the deep-rooted population base in the Northeast, increase the awareness of cruise tourism, develop a variety of cruise products in terms of routes, days, themes, prices, etc. for customers of different age groups and income ranges, dig deeper into potential customers Market, and enhance the consumption demand of domestic tourism internal circulation. 
4.2. Forecast of the Number of Outbound Tourists. The number of outbound tourists is generally closely related to the local population. Dalian Port can attract tourists from the province and attract tourists from the three northeastern provinces. However, the new corona-virus pandemic in early 2020 has had a huge negative impact on the world cruise industry. Taking Royal Caribbean Cruises as an example, its annual revenue in 2020 is US\$2.209 billion, a decrease of $79.83 \%$ from 2019 [17]. The gray model data uses a small amount of incomplete information to make a vague longterm description of the development law of things. However, the new corona-virus is not a long-term influencing factor, so abnormal data for 2020 and 2021 have been removed.

Analysis of population age structure in Heilongjiang (Table 3) Province: the population age structure of Heilongjiang Province shows an aging trend. In the past ten years, except in 2010, the number of people aged 15-64 has gradually declined, with an average annual decline of $0.40 \%$. In recent years, the rate of decline of this indicator has exceeded $0.5 \%$; in 2018, the decline was the most significant, which was $1.33 \%$. However, the number of people aged 65 and over has gradually increased, with an average growth rate of $3.3 \%$, and the growth rate of this indicator has been higher than the average level in recent years.

It is estimated that, in 2018-2020, 2021-2025, and 2026-2030, the population growth rate of Heilongjiang Province aged $15-64$ will be $-1 \%,-1.2 \%$, and $-1.5 \%$, respectively, and the population growth rate of Heilongjiang Province aged 65 and above will be, respectively, 5\%, 6\%, and $7 \%$, and the population age structure of Heilongjiang Province in 2020, 2025, and 2030 is shown in Table 4.

4.2.1. Analysis of Population Age Structure in Jilin Province. The age composition of the population of Jilin Province also shows a certain degree of aging in general. However, the number of populations of different ages fluctuates wildly. However, overall, the number of people aged 15-64 is decreasing, with an average growth rate of $-1.03 \%$, and the number of people aged 65 and above is increasing year by year, with an average growth rate of 5.28\% (Table 5).

It is estimated that, in 2018-2020, 2021-2025, and 2026-2030, the population growth rate of the population aged 15-64 in Jilin Province will be $-0.9 \%,-1 \%$, and $-1.1 \%$, respectively, and the population growth rate of the population aged 65 and over in Jilin Province will be, respectively, $2 \%, 4 \%, 6 \%$; the population age structure of Jilin Province in 2020, 2025, and 2030 is shown in Table 6.

\subsubsection{Analysis of Population Age Structure in Liaoning} Province. The population of Liaoning Province has maintained a relatively stable level and has also shown a downward trend in the past five years (Table 7).

It is estimated that the total population in 2020, 2025, and 2030 will be 43.4 million, 43 million, and 42.5 million, respectively. The proportion of the population aged 15-64 is steadily declining year by year, and it is estimated that the proportion will be $72 \%, 67 \%$, and $62 \%$ in 2020, 2025, and 2030, respectively. The proportion of the population aged 65 and above has steadily increased year by year. It is estimated that the proportions will be $17 \%, 22 \%$, and $27 \%$ in 2020,2025 , and 2030, respectively. The population age structure of Liaoning Province in 2020, 2025, and 2030 is shown in Table 8.

Concerning the age composition and market penetration of cruise tourists in China, if $0.1 \%, 0.15 \%$, and $0.2 \%$ of people aged 15-64 in the three northeastern provinces choose cruise travel in 2020, 2025, and 2030, 79,000 will be generated, 111,000 and 137,000 outbound tourists from cruise ships (Table 9). If in 2020, 2025, and 2030, $0.1 \%, 0.3 \%$, and $0.6 \%$ of older adults aged 65 and over choose cruise travel in the three northeastern provinces, there will be 16,000,63,000, and 164,000 older adults traveling abroad on cruise ships.

4.3. Forecast of the Number of Inbound Tourists. Analysis of the number of inbound tourists in Heilongjiang Province dropped significantly in 2015 and started to pick up in 2016, but the growth rate has declined year by year (Table 10).

It is estimated that the average annual growth rate of inbound tourists in Heilongjiang from 2018 to 2020, 2021-2025, and 2026-2030 will be 3\%, 4\%, and 5\%. Based on this, we can calculate the overseas tourism in Heilongjiang in 2020, 2025, and 2030. The predicted number of people is 1.158 million, 1.409 million, and 1.798 million, respectively. If $0.1 \%, 0.3 \%$, and $0.5 \%$ of the inbound tourists arrive by Dalian Port International Cruise Line, then the inbound cruise tourists will be 10 thousand, 4 thousand, and 9 thousand, respectively.

Analysis of the number of inbound tourists in Jilin Province has been on a growing trend before, but it has started to decline in the past two years (Table 11).

It is estimated that the average annual growth rate of inbound tourists in Jilin Province from 2018 to 2020, 2021-2025, and 2026-2030 will be $-1 \%, 0.5 \%$, and $1 \%$. Based on this, we can calculate that, in 2020, 2025, and 2030, a lot will come to Jilin from abroad. The predicted number of tourists is 1.408 million, 1.444 million, and 1.518 million, respectively. Suppose that the proportion of inbound tourists via Dalian Port international cruises is the same as that of Heilongjiang Province, $0.1 \%, 0.3 \%$, and $0.5 \%$. In that case, inbound cruise tourists will be $10,000,4,000$, and 8,000, respectively.

The number of inbound tourists in Liaoning Province dropped significantly in 2014 (Table 12). The number of inbound tourists gradually picked up in the following years, but the growth rate was not high.

It is estimated that the average annual growth rate of inbound tourists in Liaoning Province from 2018 to 2020, 2021-2025, and 2026-2030 will be $1 \%, 2 \%$, and $3 \%$ (Table 13). It is possible to calculate overseas tourism in Liaoning in 2020, 2025, and 2030. The predicted number of people is 2.936 million, 3.242 million, and 3.758 million, respectively. If $0.5 \%, 1 \%$, and $2 \%$ of the inbound tourists are in the form of cruise ships, the number of inbound cruise tourists will reach $15,000,32,000$, and 75,000, respectively.

With comprehensive entry and exit forecast results in 2020, 2025, and 2030, the number of international cruise ships in the three northeastern provinces will reach 112,000, 214,000, and 401,000 (Table 14). 
Table 3: Age composition of the population in Heilongjiang Province.

\begin{tabular}{ccccc}
\hline Year & Population aged 15-64 (10,000 people) & Growth rate (\%) & Population 65 years and over (10,000 people) & Growth rate (\%) \\
\hline 2009 & 2999.2 & - & 362.7 & - \\
2010 & 3056.0 & 1.89 & 318.9 & -12.08 \\
2011 & 3054.2 & -0.06 & 326.3 & 2.32 \\
2012 & 3041.1 & -0.43 & 340.9 & 4.47 \\
2013 & 3026.0 & -0.50 & 358.9 & 5.28 \\
2014 & 2998.2 & -0.92 & 385.6 & 7.44 \\
2015 & 2973.4 & -0.83 & 415.5 & 6.75 \\
2016 & 2942.5 & -1.04 & 440.7 & 6.06 \\
2017 & 2926.0 & -0.56 & 455.8 & 3.43 \\
2018 & 2887.1 & -1.33 & 485.3 & 6.47 \\
\hline
\end{tabular}

Source: Heilongjiang Province Statistical Yearbook 2019.

Table 4: Forecast of Population Age Structure in Heilongjiang Province (10,000 people).

\begin{tabular}{lccc}
\hline Year & 2020 & 2025 & 2030 \\
\hline Population aged 15-64 & 2830 & 2664 & 2470 \\
Population 65 years and over & 535 & 716 & 1004 \\
\hline
\end{tabular}

Table 5: Age composition of the population in Jilin Province.

\begin{tabular}{ccccc}
\hline Year & Population aged 15-64 (10,000 people) & Growth rate (\%) & Population 65 years and over (10,000 people) & Growth rate (\%) \\
\hline 2011 & 2153.3 & - & 239.9 & - \\
2012 & 2159.1 & 0.27 & 254.4 & 6.02 \\
2013 & 2145.7 & -0.62 & 282.0 & 10.85 \\
2014 & 2108.3 & -1.74 & 302.2 & 7.16 \\
2015 & 2114.3 & 0.28 & 309.5 & 2.41 \\
2016 & 2052.9 & -2.90 & 301.1 & -2.69 \\
2017 & 2022.6 & -1.48 & 336.4 & 11.70 \\
2018 & 2002.5 & -0.99 & 343.9 & 2.24 \\
\hline
\end{tabular}

Source: 2011-2018 National Economic and Social Development Statistical Bulletin of Jilin Province.

Table 6: Forecast of Population Age Structure in Jilin Province (10,000 people).

\begin{tabular}{lccc}
\hline Year & 2020 & 2025 & \\
\hline Population aged 15-64 & 1967 & 1870 & 2030 \\
Population 65 years and over & 358 & 436 & 1769 \\
\hline
\end{tabular}

Table 7: Age composition of the population in Liaoning Province.

\begin{tabular}{cccc}
\hline Year & $\begin{array}{c}\text { Total population of Liaoning province }(10,000 \\
\text { people })\end{array}$ & $\begin{array}{c}\text { Proportion of population aged 15-64 } \\
(\%)\end{array}$ & $\begin{array}{c}\text { Proportion of population aged } 65 \text { and over } \\
(\%)\end{array}$ \\
\hline 2010 & 4375 & 78.27 & 10.31 \\
2011 & 4383 & 78.26 & 10.65 \\
2012 & 4389 & 78.04 & 11.16 \\
2013 & 4390 & 77.86 & 11.52 \\
2014 & 4391 & 77.37 & 12.1 \\
2015 & 4382 & 76.79 & 12.82 \\
2016 & 4378 & 76.1 & 13.51 \\
2017 & 4369 & 75.38 & 14.35 \\
2018 & 4359 & 73.87 & 15.17 \\
\hline
\end{tabular}

Source: Liaoning Province 2018 Statistical Yearbook and National Economic and Social Development Bulletin.

4.4. Comprehensive Forecast Results. Comprehensively considering the prediction results of the two methods, it is obtained that, in 2020, 2025, and 2030, Dalian Port
International Cruise Line will receive approximately $110,000,200,000$, and 360,000 inbound and outbound tourists, respectively (Table 15). 
Table 8: Forecast of Population Age Structure in Liaoning Province (10,000 people).

\begin{tabular}{lccc}
\hline Year & 2020 & 2025 & 2030 \\
\hline Population aged 15-64 & 3125 & 2881 & 2635 \\
Population 65 years and over & 738 & 946 & 1148 \\
\hline
\end{tabular}

TABLE 9: Forecast of the number of outbound tourists from cruise ships (10,000 people).

\begin{tabular}{lccc}
\hline Year & 2020 & 2025 & \\
\hline Number of tourists aged 15-64 & 7.9 & 11.1 & 2030 \\
Number of visitors 65 years and older & 1.6 & 6.3 & 13.7 \\
Total & 9.5 & 17.4 & 16.4 \\
\hline
\end{tabular}

Table 10: Number of inbound tourists in Heilongjiang Province from 2009 to 2018.

\begin{tabular}{lcc}
\hline Year & Number of inbound tourists in Heilongjiang (person times) & Growth rate (\%) \\
\hline 2009 & 1425122 & - \\
2010 & 1724238 & 20.98 \\
2011 & 2065195 & 19.77 \\
2012 & 2076165 & 0.53 \\
2013 & 1528554 & -26.38 \\
2014 & 1417227 & -7.28 \\
2015 & 834716 & -41.10 \\
2016 & 957038 & 14.65 \\
2017 & 1038765 & 8.54 \\
2018 & 1091568 & 5.08 \\
\hline
\end{tabular}

Source: Heilongjiang Statistical Yearbook 2014-2019.

Table 11: Number of inbound tourists in Jilin Province from 2009 to 2018.

\begin{tabular}{lcc}
\hline Year & Number of inbound tourists in Jilin province (person times) & Growth rate (\%) \\
\hline 2009 & 680528 & - \\
2010 & 820062 & 20.50 \\
2011 & 993204 & 21.11 \\
2012 & 1182689 & 19.08 \\
2013 & 1273559 & 7.68 \\
2014 & 1376852 & 8.11 \\
2015 & 1480994 & 7.56 \\
2016 & 1619530 & 9.35 \\
2017 & 1484300 & -8.35 \\
2018 & 1436802 & -3.20 \\
\hline
\end{tabular}

Source: Jilin Province 2010-2018 Statistical Yearbook, Jilin Province 2018 National Economic and Social Development Statistical Bulletin.

Table 12: Number of inbound tourists in Liaoning Province from 2009 to 2018.

\begin{tabular}{lcc}
\hline Year & Number of inbound tourists in liaoning province (person times) & Growth rate (\%) \\
\hline 2009 & 2931954 & - \\
2010 & 3617999 & 23.40 \\
2011 & 4103329 & 13.41 \\
2012 & 4731340 & 15.30 \\
2013 & 5031286 & 6.34 \\
2014 & 2607019 & -48.18 \\
2015 & 2640052 & 1.27 \\
2016 & 2736658 & 3.66 \\
2017 & 2788464 & 1.89 \\
2018 & 2877694 & 3.20 \\
\hline
\end{tabular}

Source: Liaoning Province 2018 Statistical Yearbook, Liaoning Province 2018 National Economic and Social Development Statistical Bulletin.

4.5. Grey Forecast Based on the Development Trend of Cruise Reception in Dalian Port. The gray prediction model is a part of the gray system theory, which was put forward by Deng
[18] in 1982. Its main function is the effective processing of incomplete data analysis, modeling, prediction, decisionmaking, and control [19]. 
TABLE 13: Forecast of the number of inbound tourists from cruise ships $(10,000$ people).

\begin{tabular}{lccc}
\hline Year & 2020 & 2025 & 2030 \\
\hline Heilongjiang province & 0.1 & 0.4 & 0.8 \\
Jilin province & 0.1 & 0.4 & 0.9 \\
Liaoning province & 1.5 & 3.2 & 7.5 \\
Total & 1.7 & 4.0 & 9.2 \\
\hline
\end{tabular}

TABLE 14: Forecast of the number of inbound and outbound tourists from cruise ships (10,000 people).

\begin{tabular}{lccc}
\hline Year & 2020 & 2025 & 2030 \\
\hline $\begin{array}{l}\text { Number of outbound tourists from cruise } \\
\text { ships }\end{array}$ & 9.5 & 17.4 & 30.1 \\
Number of inbound tourists from cruise ships & 1.7 & 4.0 & 9.2 \\
Total & 11.2 & 21.4 & 40.1 \\
\hline
\end{tabular}

Dalian Port is the first city in the country to open a cruise tourism business. However, the scale growth rate is relatively slow (Table 16).

Calculate the level ratio of the original sequence and the one-time cumulative sequence of the statistical data of the number of inbound and outbound tourists from international cruise ships in Dalian Port, and the results are shown in Table 17.

Since the sample size is small, and the sequence ratio is within the tolerable coverage inter$\operatorname{val}\left(X=\left(e^{-2 / n+1}, e^{2 / n+1}\right)=\left(e^{-0.4}, e^{0.4}\right)=(0.6703,1.4918)\right)$, which meets the requirements of gray prediction, a $\operatorname{GM}(1,1)$ gray model can be established for prediction. Build a matrix, where the grey system is a differential equation established for discrete sequence, and $\operatorname{GM}(1,1)$ is a first-order differential model:

$$
\frac{\mathrm{d} x}{\mathrm{~d} t}+a x=u \quad \mathrm{GM}(1,1)
$$

The discrete form and prediction formula are as follows:

$$
\begin{aligned}
& \Delta^{(1)}\left(x^{(1)}(k+1)\right)+a(x(k+1))=u \\
& \widehat{x}^{(1)}(k+1)=\left[x^{(1)}(1)-\frac{\widehat{u}}{a}\right] e^{-\widehat{a} k}+\frac{\widehat{u}}{a} .
\end{aligned}
$$

Known from the derivative definition,

$$
\frac{\mathrm{d} x}{\mathrm{~d} t}=\lim _{\Delta t \longrightarrow 0} \frac{x(t+\Delta t)-x(t)}{\Delta t} .
$$

When it is tiny, and the small unit 1 is used, it is approximated by
TABLE 15: Comprehensive forecast results of the number of inbound and outbound tourists received by Dalian Port International Cruise Line (10,000 people).

\begin{tabular}{lccc}
\hline Year & 2020 & 2025 & 2030 \\
\hline $\begin{array}{l}\text { Number of cruise passengers entering and } \\
\text { exiting }\end{array}$ & 11 & 20 & 36 \\
\hline
\end{tabular}

$$
\begin{aligned}
& x(t+1)-x(t)=\frac{\Delta x}{\Delta t} \\
& \frac{\Delta x}{\Delta t}=x(k+1)-x(k)=\Delta^{(1)}(x(k+1)) \\
& \frac{1}{2}\left[x^{(i)}(i)+x^{(i)}(i-1)\right],(i=2,3, \ldots, N) \\
& x^{(i)}=\frac{1}{2}\left[x^{(i)}(i)+x^{(i)}(i-1)\right],(i=2,3, \ldots, N) \\
& x^{(1)}(k+1)=\frac{1}{2}\left[x^{(1)}(k+1)+x^{(1)}(k)\right] .
\end{aligned}
$$

After finishing,

$x^{(0)}(k+1)=a\left[-\frac{1}{2}\left(x^{(1)}(k)+x^{(1)}(k+1)\right)\right]+u$.

Written as a matrix expression,

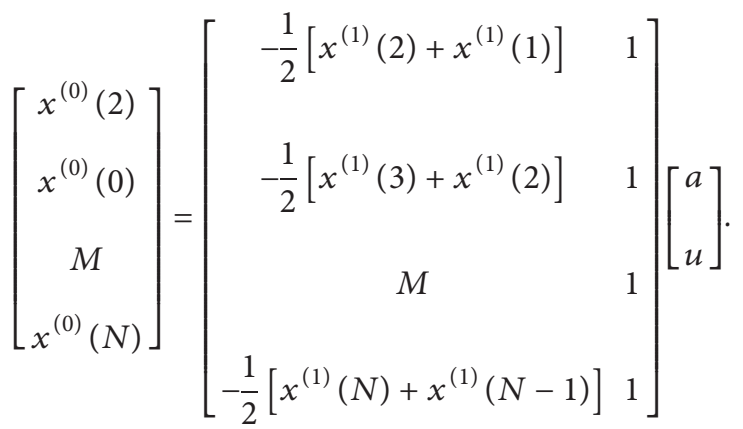


Table 16: The number of international cruise ships and inbound and outbound tourists received by Dalian Port in $2016-2019$.

\begin{tabular}{lccc}
\hline Year & Number of international cruise ships received (ships) & Number of inbound and outbound tourists (person-times) & Growth rate (\%) \\
\hline 2016 & 26 & 64801 & - \\
2017 & 31 & 69072 & 6.59 \\
2018 & 37 & 84470 & 22.29 \\
2019 & 39 & 88507 & 4.78 \\
\hline
\end{tabular}

Source: "2017 China Port Yearbook"."

TABLE 17: The number of inbound and outbound tourists from international cruise ships received by Dalian Port GM $(1,1)$ preprocessing.

\begin{tabular}{lcccc}
\hline Year & 2016 & 2017 & 2018 & 2019 \\
\hline Serial number & 1 & 2 & 3 & 4 \\
$x^{(0)}(k)$ & 64801 & 69072 & 84470 & 88507 \\
Level ratio & - & 0.938 & 0.818 & 0.954 \\
$x^{(1)}(k)$ & 64801 & 133873 & 218343 & 306850 \\
\hline
\end{tabular}

$$
\begin{aligned}
& y=\left(x^{(0)}(2), x^{(0)}(3), L, x^{(0)}(N)\right)^{\mathrm{T}} \\
& B=\left(\begin{array}{c}
-\frac{1}{2}\left[x^{(1)}(2)+x^{(1)}(1)\right] 1 \\
-\frac{1}{2}\left[x^{(1)}(3)+x^{(1)}(2)\right] 1 \\
-\frac{1}{2}\left[x^{(1)}(4)+x^{(1)}(3)\right] 1
\end{array}\right) \\
& y=\left[\begin{array}{l}
\left.x^{(0)}(2), x^{(0)}(3), x^{(0)}(4)\right]^{\mathrm{T}} \\
\widehat{U}=\left(\begin{array}{c}
\widehat{a} \\
\widehat{u}
\end{array}\right)=\left(B^{\mathrm{T}} B\right)^{-1} B^{\mathrm{T}} y .
\end{array}\right.
\end{aligned}
$$

The time response equation is

$$
x^{(1)}(k+1)=\left[x^{(1)}(1)-\frac{\widehat{u}}{\widehat{a}}\right] e^{-\widehat{a} k}+\frac{\widehat{u}}{\widehat{a}} .
$$

Substituting the samples, the gray model's development coefficient -a, gray action amount $u$, and time response equation can be calculated as

$$
\left\{\begin{array}{l}
-\widehat{a}=0.1175 \\
\widehat{u}=59605.38 \\
x^{(1)}(k+1)=\left[x^{(1)}(1)+507279.8\right] e^{0.1175 k}-507279.8 .
\end{array}\right.
$$

Bringing the required years into the equation, the number of tourists in 2020, 2025, and 2030 will be approximately $101,000,183,000$, and 329,000 , respectively (Table 18).

We can conclude that the answers given by the model are consistent with the data we expected.

After excluding the negative impact of the new coronavirus (data for 2020 and 2021 are not used), we can find that the operation of Dalian Port has played a positive role in its development. It has also played a guiding role in developing major domestic cruise ports.

\section{Suggestions and Countermeasures for the Development of Domestic Cruise Ports}

\subsection{Construction and Development Model of Cruise Home port: Home Port Investment Model}

5.1.1. PPP Mode Is Recommended for Cruise Home Port Construction. As a supporting facility for the cruise home port, the construction of the cruise port not only includes the construction of infrastructure and operating facilities, but also requires investment in the development of supporting facilities. As the requirements for the large-scale cruise ship are increasing, the development and investment of the cruise terminal are constantly increasing, billions. In addition, the development of cruise home ports involves a wide range, requires extremely high professionalism, and is complicated in construction, resulting in a long construction period. Therefore, the PPP model of public interest and scientific management and operation is very suitable for the development and construction of cruise home ports. Compared with the traditional model, the PPP model has the advantages of reducing the financial burden of the public sector and improving the efficiency of the supply of public products and services and has been more and more widely used in various countries [20-22]. However, the development of PPP in China is not mature. Due to the monopoly of stateowned capital in the field of infrastructure construction, social capital is relatively unfamiliar with this field and lacks relevant experience in investment, financing, and operation management. The enthusiasm for participating in PPP projects is limited [20].

5.1.2. Attracting Capital, Mainly Internationally Renowned Cruise Companies. The single investment subject, lack of market-oriented operation, and inflexible management mode severely restrict the healthy development of cruise ports. Therefore, professional technology and management experience should be used as the primary measurement criteria for external capital selection of cruise home ports. The government should base on cruise home ports. Development planning, market demand, port development, economic benefits, etc. put forward implementation requirements and management scope, comprehensively evaluate the feasibility of external capital from technology, finance, law, and environment, and design a standard system that meets the requirements and specifications. The 
TABLE 18: Grey prediction value of the number of international cruise inbound and outbound tourists received by Dalian Port (persontimes).

\begin{tabular}{lccc}
\hline Year & 2020 & 2025 & 2030 \\
\hline Number of cruise passengers entering and exiting & 101483 & 182640 & 328697 \\
\hline
\end{tabular}

government, ports, and external capital should be based on partnership, benefit-sharing, and risk-sharing principles and fulfill their responsibilities according to the scope of cooperation. The choice of external capital should pay attention to the development and operation of cruise ports, pursue economic interests, and pay attention to public interests and jointly contribute to the development of cruise home ports. Therefore, it is necessary to analyze the cruise industry chain's development characteristics and clarify each link's relevant requirements in the development and operation of the cruise home port that is an essential basis for selecting external capital. Therefore, internationally renowned cruise companies are the primary target in attracting external funds to join the cruise home ports construction. Well-known cruise companies have substantial funds and rich management experience, which can largely compensate for the cruise operations of Dalian Port management. In recent years, cruise companies have accelerated their ports and have equipped their ships with exclusive cruise terminals [23]. Moreover, the cruise company aims to satisfy passengers' demand for cruise ships by providing larger and more diversified types of ships [24].

\subsubsection{Strengthen the Risk Management of the Capital Co-} operation Process. The PPP model of cruise home port construction involves multiple subjects, multiple links, and long duration. It requires a sound institutional system to support its capital cooperation, scientific and reasonable risk-sharing, and seeking the best risk-sharing method for all parties, to better grasp the risks. Carry out risk assessment and management. At the same time, the PPP model lacks experience in the application of Chinese cruise ports. For a long time, the government has played a dominant role in port development and management. Compared with foreign countries, the PPP model has more difficulties in advancing in China, and the process is more complicated. Therefore, the PPP model in the advancement process should be gradual. In response to the development needs of the cruise home port, choose a suitable construction model. In addition, the cruise port is a public product and cannot be fully market-oriented. It needs to pay attention to public interests at all times. Therefore, when the PPP model is applied in cruise ports, it is necessary to solve the return on investment reasonably. According to the current development of the cruise industry in Dalian, the number of cruise voyages operated and received is still relatively small, and it cannot meet the capital requirements in the early stage. The government should provide specific policy support for investment return requirements, such as a fixed return on investment, financial subsidies, and tax incentives. It will help attract external capital to participate in constructing the Dalian cruise home port. Therefore, in introducing external capital in cooperation, to clarify the risk allocation of all parties, it is also necessary to grasp the changes in the macroand microenvironments to reduce the uncertainty of cooperation construction.

\subsection{Home Port Business Model}

5.2.1. Cooperation and Development between Cruise Ports. Dalian Port should strengthen cooperation with port and tourist cities, distinguish between types and levels with other cruise ports, dislocation competition, and orderly competition, pay attention to its comparative advantages, in the competition and cooperation, and other cruise ports to jointly develop the source of tourist market, develop cruise line products, jointly improve the service level of the port, solve the difficulties of lack of profitability and insufficient revenue capacity, and form an emergency linkage mechanism in case of emergencies and other cooperation strategies. At the same time, under the great opportunity of the "Eastward Movement" of the global cruise market, we will study and formulate effective Dalian Port cruise home port development and management policies and measures as soon as possible to promote the timely integration of Dalian cruise home port into the international network. Dalian Port should actively promote the mutual home port routes and realize the cooperative development of each other's home ports. The cruise routes of multiple home ports have ports on the same cruise route as the home ports of each other, the source of tourists from the same cruise ship is diversified, and shore tourist destinations are more abundant. Visitors' freedom of boarding and disembarking has been significantly improved while promoting outbound travel and inbound travel. Dalian Port can actively seek cooperation with ports that also cruise home ports to promote the implementation of multiple home port cruise routes.

\subsubsection{Cooperative Management between Hinterland Cities.} Rich and high-quality tourism resources are the biggest attraction of tourism activities. China is a big tourist country with abundant tourism resources. The home port of Dalian cruises should strengthen tourism cooperation with hinterland cities to form a resource-rich hinterland tourism circle. Choose suitable cities at home and abroad to jointly operate and develop tourism products. In China, cooperation with tourism cities in the Northeast, Shandong, and other regions can be strengthened to develop tourism routes with northern characteristics. Tourists can choose to take a cruise to reach the tourist destination; In foreign countries, it can cooperate with China's economic partner tourist cities to strengthen the exchange of tourists from both sides by taking cruise ships; according to market demand, focus on cooperation with tourist cities in Southeast Asia. Dalian port 
city's convenient transportation integrates regional tourism resources, design tourism routes, and provide cruise tourists with the most suitable tourism products, by tapping the characteristics of the tourism resources of hinterland cities, innovating the cooperative operation model with hinterland cities, improving the operation ability of Dalian cruise home port, and forming an operation management model that meets the development needs of Dalian cruise home port.

\subsubsection{Cruise Home Port and Industrial Group Development.} The construction and operation of cruise home ports have made a significant contribution to the regional economy. Its contribution is related to the one-stop cruise ship berthing, maintenance, and ship supply centered on the operation of cruise home ports-tourist leisure, entertainment, sightseeing, catering, etc. Comprehensive commercial tourism facilities are related to the completeness of the cruise home port industrial chain, such as cruise company headquarters, travel agencies, and cruise financial service institutions. The operation of the home port of Dalian cruises should fully consider the development of cooperation with supporting industries. In actual operations, it should fully consider the close connection with the development of urban tourism, entertainment, and service industries and give full play to the brand value of the cruise home port and the advantages of passenger flow to promote Dalian's tourism, commercial and service cluster development. It relied on the home port of Dalian cruise ship to build a new-generation CBD integrating finance, commerce, tourism, and leisure, with highly integrated elements and functions, forming a modern large-scale comprehensive business center and becoming a consumer destination. With Dalian's cruise home port as the core, the extended cruise industry as the backing, and the two major industries of tourism and leisure and port and shipping services as the pillars, the cruise industry will be built into Dalian's advantageous industry.

With the expansion of the cruise market, cruise ships are transforming from high-class specific tourism in the past to mass tourism for the middle class. With the improvement of the cruise service network, the cruise industry is constantly expanding into new sea areas, breaking the previous growth model, and growing rapidly and continuously. According to the gray system model prediction, during 2020-2030, the number of inbound and outbound tourists from cruise ships will double every five years through the analysis of the predictive model. The main factors affecting the number of tourists are the number of cruise ships, the scale of cruise ships, and the routes. The potential factors are market potential and market attractiveness. Therefore, Dalian Cruise should be improved from the following aspects:

\subsection{Resource Guarantee}

5.3.1. Establish a Cruise Industry Development Fund. Strive for national policy financial institutions to strengthen financial services for the cruise industry in Dalian and support the establishment of a cruise industry development fund. The cruise industry will be included in the special funds for the future industrial development of Dalian, and the projects supported by the special funds for the development of Dalian's modern logistics industry will be given vital support. Increase the support of Dalian's related industry funds to the economic development of cruise ships, and list vital areas and key projects such as cruise research and development, design, manufacturing, tourism, and operation into the priority support range. Promote the implementation of the "Administrative Measures for the Special Funds for Tourism Development in Dalian," make good use of the special funds for Dalian's tourism development, and provide substantive support for the construction of cruise-related infrastructure, the solicitation and operation of cruise ships at the port of departure.

\subsubsection{Increase Fiscal and Financial Support. Dalian should} arrange a certain amount of financial funds every year to implement the cruise tourism industry development incentive policy to cultivate and support the development of the international cruise market and the cruise industry chain for 3-5 consecutive years. For the newly established cruise company in Dalian, rewards will be given based on the certification standards of the cruise headquarters to attract cruise companies to register their operating organizations in the local area. Establish special support funds for cruise operation and development in Dalian, provide continuous subsidies for cruise operations for three years, and encourage ports, cruise companies, travel agencies, etc., in terms of increasing the number of cruise tourists, cruise ships, normal operations, and improving port services. After the subsidy policy expires, it is determined whether to extend the subsidy period according to the market conditions in Dalian and the implementation of cruise policies in other cities. For cruise companies that choose Dalian Port Cruise Center as a port of departure or a visiting port to operate, increase the number of cruise routes, give different rewards according to cruise class and voyage, and encourage cruise ships to stop and increase the number of voyages. For cruise companies that operate in the off-season of cruise travel (tentatively 1-5, September, November, and December each year, except for national holidays and winter vacation flights), cruise ships operating from the Dalian Port Cruise Center as their home port, and cruise companies that organize inbound nonmainland tourists, a certain amount of reward will be given to each person per ship. An additional one-time reward will be given to the cruise company that organizes and transports inbound tourists to a certain amount each year. For travel agencies to expand their cruise business, organize a certain number of tourists to the Dalian International Cruise Center to take a cruise and stay in qualified hotels in Dalian for more than one night, the price level of the hotel will be reviewed, and a certain amount will be given according to the number of people award. Guide insurance institutions and commercial banks to explore financial products for the cruise industry, encourage cruise financial services and product innovation, extend, optimize, and improve the cruise tourism industry chain, and enhance international competitiveness. The newly introduced cruise- 
related associations, research institutes, transaction service agencies, qualification certification agencies, and other functional institutions will be recognized as one-time investment rewards at the international and national levels. Encourage innovation and entrepreneurship in the cruise field and attract more social capital to participate in cruise industry investment. Provide transportation and catering subsidies to customs, border inspections, and other joint inspection units at ports to further improve port clearance efficiency and encourage ports to improve cruise services.

\subsubsection{Overall Planning and Coordination of Land Resources.} Coordinate and straighten out the land use rights around the Dalian Port International Cruise Center, support land and sea use for cruise tourism projects, and lay the foundation for the development of the Dalian Port cruise industry. Expand the source of land used by cruise ship headquarters and strengthen the precise supply of land. In terms of urban planning, land use, etc., focus on supporting cruise headquarters companies to independently or jointly build headquarters office buildings to form a cruise headquarters cluster area.

\subsection{Talent Guarantee}

5.4.1. Introduce a Cruise Human Resource Development Policy. Intensify the introduction and training of cruise talents, formulate a catalog of cruise talents, integrate cruise talents introduction management service resources, and integrate the international cruise industry economy, cruise design, manufacturing and maintenance, cruise seafarers, cruise sea passengers, cruise operation, and management involved in the cruise industry chain. Professional talents, such as sales of cruise products, are included in Dalian's shortage of talents catalog. Policy support for the settlement, housing, and other aspects will be given. Actively explore the cruise personnel training mechanism, encourage the cooperation of shipping, tourism, and maritime education institutions, and form a "three-in-one" cruise human resource development system featuring higher education, social training, and talent introduction. Establish an international cruise expert resource database platform, and promote the exchange of high-level cruise talents through joint appointments, pairing, and coconstruction.

5.4.2. Strengthen the Support of the Cruise Talent System. Establish and improve the cruise tourism academic education and vocational education training system, encourage local universities and colleges in Dalian to attract international forces, provide relevant educational resources within the United Nations, broaden channels, and carry out cruise professional education and skills training through a variety of school-running forms. Support tourism administration departments to join professional education institutions to introduce international cruise sales certification qualifications and train professional and technical personnel for cruise sales. Encourage and support local educational institutions to set up marine transportation programs, train marine transportation personnel on a large scale, and become a training base/center for marine transportation in China. By cooperating with foreign training institutions to hold training assessments, carry out course research and development, provide employment internships and other methods, and provide reliable personnel guarantee and intellectual support for the development of Dalian cruise tourism. Give full play to the advantages of talent gathering in Dalian universities, adhere to the integration of production, education, and research, increase school-enterprise cooperation, support universities in optimizing cruise-related curriculum settings, and build training bases with cruise ports and cruise companies to enhance professionalism with a global perspective and an international perspective. The quality of talent training provides talent guarantee and intellectual support for the development of the cruise industry in Dalian and even the whole country. Actively create conditions to select capable and high-quality cruise talents to study in advanced countries and regions, carry out advanced cruise research and training, and train senior cruise management talents. Strengthen the follow-up education and training of cruise tourism employees and include the cruise vocational training project into the Dalian vocational skills training subsidy scope. Establish an international cruise tourism talent training base to create a highland for China's cruise tourism talents.

\section{Conclusion}

This article is based on the development of Dalian Port in recent years and the data predicted by the gray model. Fully agree with the operation mode and development expectations of Dalian Port. Through detailed discussions on the business model of Dalian Port (land resources, human resources, market development, investment models, etc.), it enables the major cruise ports to have a deep understanding of the operation mode of the Dalian Port cruise port and provides a good direction and guidance for the development of other cruise ports in China.

\section{Data Availability}

The data are available upon request.

\section{Conflicts of Interest}

The authors declare that they have no conflicts of interest.

\section{References}

[1] I. Ege, "The Impact of coronavirus disease (COVID-19) pandemic on cruise industry: case of diamond princess cruise ship," Mersin University Journal of Maritime Faculty, vol. 2, pp. 32-37, 2020.

[2] I. Hirohito, H. Shinya, and K. Tomoya, "The cruise industry and the COVID-19 outbreak," Transportation Research Interdisciplinary Perspectives, vol. 5, 2020. 
[3] P. L. Lim, "Influenza and SARS: The Impact of Viral Pandemics on Maritime Health," International Maritime Health, vol. 62, pp. 170-175, 2011.

[4] H. D. Freya, "Socialising tourism for social and ecological justice after COVID-19," Tourism Geographies, vol. 22, pp. 1-14, 2020.

[5] L. Dwyer and P. Forsyth, "Economic significance of cruise tourism," Annals of Tourism Research, vol. 25, no. 2, pp. 393-415, 1998.

[6] K. Galina, A. Kuchumov, and Y. Testina, "Ways to increase tourist flows in the siberian federal District," in Proceedings of the 4th International Conference on Innovations in Sports, Tourism and Instructional Science (ICISTIS 2019), January, 2019.

[7] N. Aidin, K. G. Dinesh, and J. K. Robert, "Improving revenue performance with third-degree price discrimination in the cruise industry," International Journal of Hospitality Management, vol. 89, 2020.

[8] G. B. Juan and Z. A. Sandra, "The impacts of the cruise industry on tourism destinations,"Sustainable tourism as afactor of local development, 2008, https://www.torrossa.com/en/ resources/an/4214332.

[9] S. S. J. Bell and E. Dahl, "Cruise ships and travel medicine," Essential Travel Medicine, pp. 285-291, John Wiley \& Sons, Hoboken, NJ, USA, 2015.

[10] Y. Wang, K. Jung, G. Yeo, and C. Chou, "Selecting a cruise port of call location using the fuzzy-AHP method: a case study in East Asia," Tourism Management, vol. 42, pp. 262-270, 2014.

[11] C. Bowen, P. Fidgeon, and S. J. Page, "Maritime tourism and terrorism: customer perceptions of the potential terrorist threat to cruise shipping," Current Issues in Tourism, vol. 17, no. 7, pp. 610-639, 2014.

[12] K. A. Garin, Devils on the Deep Blue Sea: The Dreams, Schemes, and Showdowns that Built America's Cruise Ship Empires, Viking Press, New York, NY, USA, 2005.

[13] Y. Yin, Z. Yu, and Z. Jiang, "Research on the financial service system for development of China's cruise industry," in Report on China's Cruise Industry, pp. 195-222, Springer, Singapore, 2018.

[14] J. Ahn and K. J. Back, "Cruise brand experience: functional and wellness value creation in cruise service," International Journal of Contemporary Hospitality Management, vol. 31, no. 5, pp. 2205-2223, 2019.

[15] C. Lim and Y. Wang, "China's post-1978 experience in outbound tourism," Mathematics and Computers in Simulation, vol. 78, no. 2-3, pp. 450-458, 2008.

[16] Cruise Industry News Quarterly (CINQ), "Ports Are Stepping up,” 2012, http://www.cruiseindustrynews.com/files1/CIN Fall AsiaSpecial.pdf.

[17] M. T. Royal, Caribbean Cruises Revenue 2006-2021, RCL, Thailand, 2006-2021.

[18] J. L. Deng, “The control problems of grey systems," Journal of Systems and Control Letters, vol. 1, no. 5, 1982.

[19] J. Gu, V. Nihil, A. Bilal, and P. Michael, "Application of grey prediction model for failure prognostics of electronics," International Journal of Performability Engineering, vol. 6, no. 5, pp. 435-442, 2010.

[20] M. Wu, W. Lv, and Q. Sun, "Optimizing price of credit default swaps for dynamic project system of public-private partnership," Discrete Dynamics in Nature and Society, vol. 2018, Article ID 7280974, 10 pages, 2018.

[21] J. Lv, M. Lin, W. Zhou, and M. Xu, "How PPP renegotiation behaviors evolve with traffic changes: evolutionary game approach," Journal of Construction Engineering and Management, vol. 147, no. 5, Article ID 04021032, 2021.

[22] J. Lv, T. An, X. Y. Tan, and Q. Zou, "How to alleviate rentseeking behaviour in performance appraisal of governmentpaid PPP projects? Tripartite evolutionary game approach," Discrete Dynamics in Nature and Society, vol. 2021, Article ID 5266167, 15 pages, 2021.

[23] A. A. Pallis, F. Parola, G. Satta, and T. E. Notteboom, "Private entry in cruise terminal operations in the Mediterranean Sea," Maritime Economics \& Logistics, vol. 20, pp. 1-28, 2018.

[24] J. P. Rodrigue and T. Notteboom, "The geography of cruises: itineraries, not destinations," Applied Geography, vol. 38, pp. 31-42, 2013. 